\title{
Article
}

\section{Evaluating policy as argument; the public debate over the first UK austerity budget}

Fairclough, Isabela

Available at http://clok.uclan.ac.uk/13174/

Fairclough, Isabela ORCID: 0000-0001-6718-2636 (2015) Evaluating policy as argument: the public debate over the first UK austerity budget. Critical

Discourse Studies, 13 (1). pp. 57-77. ISSN 1740-5904

It is advisable to refer to the publisher's version if you intend to cite from the work. http://dx.doi.org/10.1080/17405904.2015.1074595

For more information about UCLan's research in this area go to

http://www.uclan.ac.uk/researchgroups/ and search for <name of research Group>.

For information about Research generally at UCLan please go to

http://www.uclan.ac.uk/research/

All outputs in CLoK are protected by Intellectual Property Rights law, including Copyright law. Copyright, IPR and Moral Rights for the works on this site are retained by the individual authors and/or other copyright owners. Terms and conditions for use of this material are defined in the policies page.

\section{CLoK}

Central Lancashire online Knowledge www.clok.uclan.ac.uk

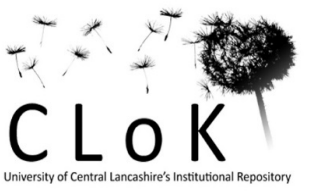




\title{
Isabela Fairclough
}

School of Journalism, Language and Communication

University of Central Lancashire, UK

Email: ifairclough@uclan.ac.uk

\section{Evaluating policy as argument: the public debate over the first UK Austerity Budget ${ }^{*}$}

\begin{abstract}
This article aims to make a methodological contribution to the 'argumentative turn' in policy analysis and to the understanding of the public debate on the UK government's austerity policies. It suggests that policy arguments are practical arguments from circumstances, goals and means-goal relations to practical conclusions (proposals) that can ground decision and action. Practical proposals are evaluated in light of their potential consequences. The article proposes a deliberation scheme and a set of critical questions for the evaluation of deliberation and decision-making in conditions of incomplete knowledge (uncertainty and risk). It illustrates these questions by analyzing a corpus of articles from five newspapers over the two months following the adoption of the first austerity Budget in June 2010. It also suggests how 'framing' functions in deliberation and decision-making, and how analysis of 'framing' can be integrated with the analysis and evaluation of argumentation.
\end{abstract}

Keywords: austerity, Budget, critical questions, decision-making, deliberation, framing, metaphor, policy evaluation, practical argument, uncertainty and risk

\section{Introduction}

The austerity policies initiated in 2010 by the UK's Conservative and Liberal-Democrat coalition government have so far involved a systematic programme of public spending cuts and tax rises aimed at reducing the budget deficit and helping Britain recover from the effects of the financial crisis. In this paper ${ }^{1}$ I will focus on the way in which the argument for austerity made by George Osborne in his first Budget speech (22 June 2010) was received by economic analysts and journalists in a range of daily newspapers, at the time when it was first made. With the benefit of hindsight, it is always possible to say that a course of action which seemed reasonable at some point in the past, in light of everything that was known or could have been known at the time, was not in fact reasonable. This is different from a situation when a course of action turns out to have been unreasonable in light of facts that could and ought to have been known at the time but were ignored or disregarded (e.g. arguably, Britain's participation in the invasion of Iraq). It is only in the former situation that the fallibility of human knowledge can be legitimately invoked as an excuse. This analysis addresses the public debate on austerity at a time when there was no hindsight, which is the typical context for practical decisions, namely a situation of incomplete knowledge -

\footnotetext{
* This version of record of the manuscript has been published and is available in Critical Discourse Studies 13(1)/2016, pp. 57-77. DOI: 10.1080/17405904.2015.1074595.
} 
uncertainty and risk - when practical proposals have to be assessed on the basis of their potential consequences, given all the knowledge available to the deliberating agents.

'Uncertainty' means that it is genuinely impossible to predict how things will turn out (i.e. there are 'unknown unknowns' that will interfere with the most carefully planned out course of action). 'Risk' means that the possible outcomes are known in principle, but which outcome will materialize is hard to predict. Uncertainty cannot be reduced to risk, as risk presupposes some calculation is possible. As Keynes (1971-89, cited in Parsons 2012) warned, economic policy involves primarily uncertainty rather than risk, as it unfolds against a background of unknown future events and developments about which little, if any, calculation of probability can be made. This notwithstanding, he argued, under pressure to act, agents often go ahead on the assumption that uncertainties are risks, that the future can be predicted in terms of what we know about the past, often with disastrous consequences - as the financial crisis has itself shown.

In addition to being an empirical study, this article develops the analytical framework for the evaluation of practical arguments in political discourse presented in Fairclough \& Fairclough (2012), where a more systematic 'argumentative turn' was advocated for the field of Critical Discourse Analysis (CDA). It thus aims to make a methodological contribution to the 'argumentative turn' in policy studies (Fischer \& Gottweis 2012) by proposing a set of critical questions for the evaluation of practical arguments in deliberative activity types. It also briefly indicates how the concept of 'framing' relates to the evaluation of argument.

For the purpose of this analysis, 461 media texts, published over the interval 15 June - 15 August 2010, were selected from The Guardian (121 articles), The Daily Telegraph (105), The Daily Mail (93), The Financial Times (92), and The Sun (50), with a combined total of around 315,000 words. ${ }^{2}$ The first section briefly introduces the concepts of practical argumentation, deliberation and critical questioning. The second provides a brief illustration of the way in which each critical question was used in the media debate on austerity in June-August 2010. The third section looks at a selection of data in more detail, in relation to one critical question, and shows how frame analysis can fit into analysis and evaluation of argumentation.

\section{Critical questions for the evaluation of policy as practical argument}

In discussing the public response to austerity policies, I start from the practical argument scheme originally defined by Walton (2006, 2007a, 2007b), which I am re-expressing as argumentation from circumstances, goals and a means-goal relation (Fairclough \& Fairclough 2011, 2012):

The agent is in circumstances $C$.

The agent has a goal $\mathrm{G}$ (generated by a particular normative source.)

Generally speaking, if an agent does $A$ in $C$, then $G$ will be achieved.

Therefore, the Agent ought to do A.

I suggest the following situation as a starting point: an (individual or collective) agent having a stated goal $G$ in a set of circumstances $C$, proposing a course of action A (or several such proposals), that would presumably transform their current circumstances into the future state-of-affairs corresponding to their goal G. (The goal is underlain by a concern for the realization of some value, desire, obligation, etc.) Based on all the knowledge available, the agent is conjecturing that they 
ought to do $A_{1}$ (or $A_{2}$ or $A_{3} \ldots$ ) to achieve $G$ in circumstances $C$. In order to decide rationally, the agent should subject each of these alternatives (hypotheses) to critical testing, trying to expose potential negative consequences of each. A pragmatic argument from negative consequence (lefthand side of Figure 1) can potentially rebut the practical proposal (conclusion) itself, whereas challenges to the validity of the argument or to the truth of the premises cannot show that the proposal is unreasonable but merely that it does not follow from the premises. The pragmatic argument from negative consequence has this form:

If the agent does $A$ (adopts proposal A), consequence (effect) E will follow. Consequence $\mathrm{E}$ is unacceptable.

Therefore, the agent ought not to do A (adopt proposal A).

Van Eemeren (2010: 138-143) distinguishes among abstract genres (e.g. deliberation), activity types (e.g. parliament or policy debate) and concrete speech events (e.g. particular examples of such debates). Deliberation is a genre common to many activity types whose intended outcome is a normative-practical conclusion that can, in principle, ground decision and action. I suggest that argumentation in deliberative activity types can be succinctly represented as follows (Figure 1), where the conclusion of the practical argument from goals and circumstances (centre) is tested by a pragmatic argument from consequence (left). Any action has both intended and unintended consequences, and the latter may be foreseeable or not. From a critic's perspective, the foreseeable unintended effects (consequences) can be such that the action had better not be performed, even if the intended effect can be achieved by doing $A$. The intended effect (i.e. the goal) itself can be unacceptable. If either of these is the case, a critical objection to $A$ has been exposed and the hypothesis that the agent ought to do A has been refuted (rebutted). However, if the negative consequences, while unacceptable in principle, do not constitute critical objections against $\mathrm{A}$ (this could be because there is some 'Plan B' or mitigating strategy in place, or because they can be traded off against positive consequences), then the conclusion in favour of $A$ may still stand, in spite of these counter-considerations.

Practical claims can also be supported by arguments from positive consequence. The argument from goals can itself be seen as an argument from positive consequence. Positive consequences also include desirable side effects that are not explicitly intended (are not goals that agents start from), but can be predicted to occur. The right-hand side of Figure 1 represents the arguments from (intended or unintended) positive consequence ( $\left.E^{\prime}\right)$ that allegedly count in favour of the conclusion. Figure 1 is a development of the schema proposed in Fairclough \& Fairclough 2012, connecting two argument schemes, the practical argument from goals and the pragmatic argument from consequence; it also shows how explanations may be related to the argument. ${ }^{3}$

The decision to adopt proposal $A$ is reasonable if the hypothesis that $A$ is the right course of action has been subjected to critical testing in light of all the knowledge available and has withstood all attempts to find critical objections against it. By critical objection I understand an overriding reason why the action should not be performed, i.e. a reason that is not overridden by another reason that has normative priority in the context, in the process of 'weighing' reasons that characterizes deliberative activity types. The primary point of critical questioning is not to narrow down a range of alternative proposals to the one and only 'best' one, but to eliminate the clearly unreasonable ones from a set of alternatives. The underlying conception is a critical rationalist view of the function of argument and of rational decision-making (Miller 1994, forthcoming). 


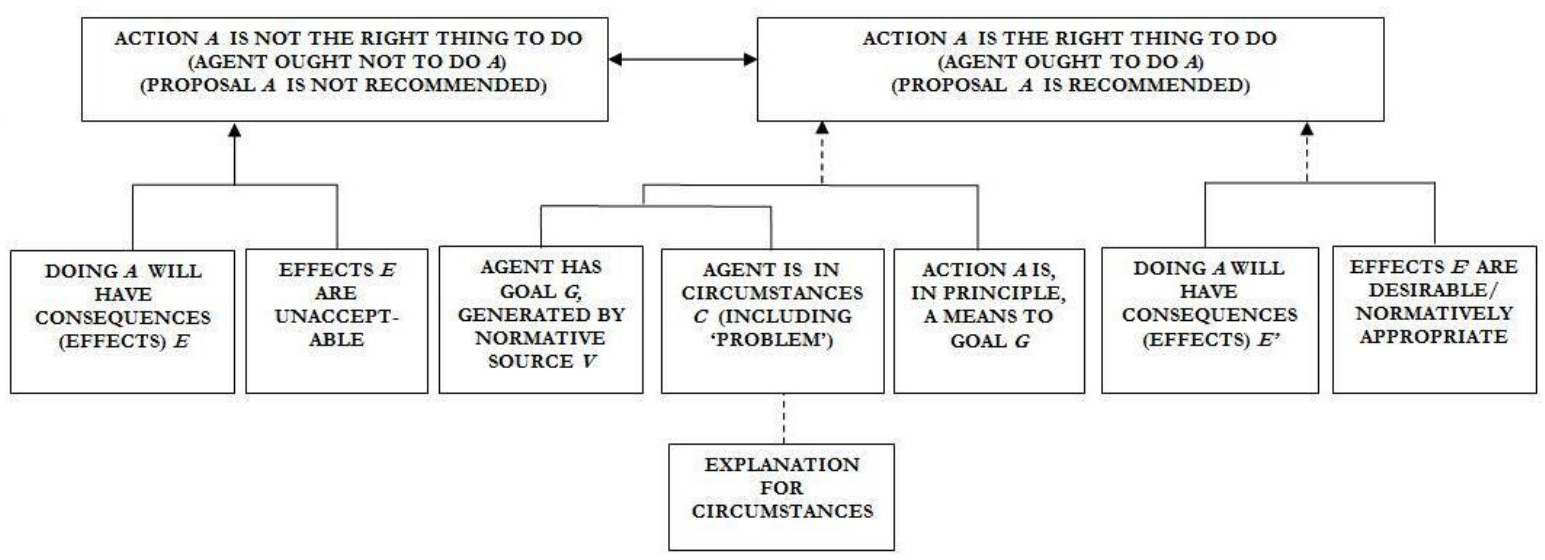

Figure 1. Proposal for the structure of practical reasoning in deliberative activity types

Walton (2007b) talks about three ways of challenging a practical argument: challenging the premises, the conclusion and the inference. In the set of questions suggested below, some critical questions (CQ4 and CQ5) attempt to test the practical proposal (conclusion) and may indicate that it is unreasonable and ought to be abandoned. Other questions (CQ1-CQ3) attempt to undermine the premises of the argument from goals, questioning their rational acceptability ('truth' for short, here). Finally, CQ6 attempts to defeat the inference from premises to conclusion, by indicating that there may be other facts that can be added to the premise set in light of which the conclusion no longer follows.

The following questions (Table 1) should be asked from the perspective of the critic, as antagonist, in order to evaluate a practical proposal (and the argument that allegedly supports it) being put forward by an arguer (as agent, or on behalf of an agent), as protagonist. The numbering of questions from 1 to 6 should not be taken to mean that they need asking in this strict order, i.e. CQ1-CQ3 before CQ4-CQ6, as the questions are of three different types. ${ }^{4}$

Challenging the rational acceptability ('truth') of the premises

CQ1 Is it true that, in principle, doing A leads to G?

CQ2 Is it true that the Agent is in circumstances C?

CQ3 Is it true that the Agent actually has the stated goals and values (motives)?

Challenging the reasonableness of the conclusion

CQ4 Are the intended consequences of $A$ (i.e. the goal) acceptable?

CQ5 Are the foreseeable unintended consequences (e.g. risks) of A acceptable? 
CQ6 [Among reasonable alternatives,] is A comparatively better in the context?

Table 1. Critical questions for the evaluation of practical arguments

Critical questioning in the format above integrates deliberation about means and deliberation about goals within a single recursive procedure. A successful challenge will redirect the deliberative process to some antecedent stage or to the starting point. If the foreseeable side effects are unacceptable, then a new practical proposal has to be made and the testing procedure will start again. If the goal itself is unacceptable, then deliberation may want to start again with a revised goal, prior to making a new conjecture about the right means to deliver it. The arguer (agent) may of course deny that any of these critical challenges have been successful. For example, s/he may deny that doing $A$ will have the predicted side effects $E$ or that those effects would be on balance unacceptable (e.g. on balance undesirable or normatively inappropriate).

\section{Challenging and defending austerity}

All of the above lines of criticism were pursued from the start in the public media debate on austerity policies in the months of June, July and August 2010. One line of attack implicitly challenged the means-goal premise (CQ1), with economists, journalists and politicians questioning the government's apparent belief in the possibility of economic recovery by means of spending cuts. Bringing examples from the Great Depression and Japan's history of stagnation, some argued that austerity, as means, always fails to deliver the intended goals. In other words, based on all available information about particular cases in the past - which indicates that, in similar situations, by killing demand, austerity has always worsened the economic situation - it is not rationally acceptable that austerity can in principle deliver economic recovery. In the Financial Times, Martin Wolf (2010b) argued that 'in the current circumstances, the belief that a concerted fiscal tightening across the developed world would prove expansionary is, to put it mildly, optimistic', if not 'heroic' - a 'mythical belief' in the 'confidence fairy', according to Paul Krugman (2010a), in the New York Times. Others claimed, on the contrary, that it is perfectly possible for austerity to lead to recovery. 'Austerity drives can unleash confidence' and 'there is every chance growth can resume even as cuts take hold'; 'though seemingly a paradox, expansionary fiscal contractions are not a figment of economists' imagination' and can be illustrated with successful examples from recent history Denmark and Ireland in the 1980s (Monson \& Subramanian 2010).

Whether or not the means-goal premise is acceptable depends on how convincing is the evidence that supports it, and the evidence was interpreted in radically different ways. In the Austerity debate hosted by the Financial Times in July 2010, those who argued for immediate fiscal retrenchment on the basis of alleged evidence for 'expansionary fiscal contraction' were accused of misinterpreting the evidence or 'rejecting the counsels of history' (DeLong 2010), but so were those who advocated postponing the cuts until growth had resumed. While, for Niall Ferguson (2010), all 
the evidence pointed to the incorrectness of the Keynesian position ('today's modern Keynesians have learnt nothing'), for Robert Skidelsky and Michael Kennedy (2010), Keynes was right to argue that 'the boom, not the slump, is the right time for austerity at the Treasury'.

If the argument does not survive critical questioning at this stage (CQ1), the arguer is expected to revise the means-goal relation, which may mean either choosing an alternative means or combining the chosen means with some other, if in itself it is insufficient in view of the goal. In the Financial Times, for example, Jeffrey Sachs (2010) argued that, while austerity is not sufficient for recovery, it should not be abandoned, but should be coupled with other policies - with 'long-term investments in physical and human capital as the proper way back to sustained growth'. 'Fiscal adjustment and higher medium-term growth' should be 'twin policy goals' (El-Erian 2010).

CQ2 amounts to asking whether the circumstances (including the 'problem') are as they are being described. Commentators both agreed and disagreed with the government's representation of the current situation in Britain: a situation of national 'emergency', an economy in ruins ('the ruins of an economy built on debt'), facing threats of insolvency similar to ones faced by Greece, where the state is 'crowding out' the private sector and the financial sector is disproportionately large compared to manufacturing. The associated explanation for the current state of affairs (it was all Labour's fault) was accepted by some and rejected by others. In The Guardian, Jonathan Freedland (2010b) argued that the case against austerity would not be made convincingly until Labour managed to 'win the blame game' and explode the 'myth .... that Brown, not bankers, caused our economic woes'. The real cause of the deficit, he said, was the bank bailout, the 'colossal borrowing Labour had to undertake in order to prevent the crash of 2008 engulfing the entire economy'; ultimately, the cause was 'the larcenous greed of bankers's. On the contrary, according to an editorial in The Sun (The Sun says, 2010) on the day of the Budget speech, 'the nation is clear who it blames for Britain's debts: LABOUR'. The crisis was caused by excessive consumption, living on borrowed money and by irresponsible state spending on a welfare system that rewards only those who prefer 'wallowing in state-sponsored idleness' (Randall 2010, in The Daily Telegraph).

The stated motives of action were also questioned (CQ3). Normally, it is taken for granted that a proposal is based on the stated goals and values. But sometimes arguments are rationalizations: the overt, stated reasons are not the real reasons, and there are other, covert reasons driving the proposed action (Audi 2006). It was argued that austerity policies are in fact ideology-driven: 'the real reason has to do a lot with ideology: the Tories are using the deficit as an excuse to downsize the welfare state' while using the 'the official rationale' that 'there is no alternative' (Krugman 2010b). The government's 'real goal' is, allegedly, to 'complete the demolition job on welfare states that was started in the 1980s' (Elliott 2010a).

According to the Budget speech, the government was committed both to being effective in reducing the deficit and to doing so in a way that was fair to the population. Constant invocation of this double (and often triple) commitment ('responsibility, freedom, fairness') implied that the proposal being presented to the public as the result of deliberation was informed by all these normative sources, that none had been sacrificed. However, many journalists cited the Chancellor's expressions 'tough but fair' and 'we are all in this together' in order to question that fairness was a genuine concern - see the Guardian headlines: 'Osborne's claims of fairness are now exposed as a fraud' (Milne 2010) or 'Rooted in deficit-slashing superstition, this budget will hit the poor hardest: 
The fairness Osborne trumpets is skin deep' (Freedland 2010a). This is Polly Toynbee's comment, in The Guardian, on the morning after the Chancellor's Budget speech:

The word "progressive" crossed the floor yesterday and entered the lexicon of the right. If these were the promised "progressive cuts", then the word vanished into the realm of double-think. True, some Lib Dem yellow ribbons decorated the handle of the axe, but they barely impeded the swing of the executioner's arm. (...) "Fairness" repeated over and over will not make it so. (...) The coalition has opted for cuts far beyond anything the markets expected or demanded. Why? The reason can only be ideological. (Toynbee 2010)

Overall, The Guardian's verdict was that the Budget was 'Tough but Unfair' (headline), 'regressive' rather than 'progressive', 'a classic Tory budget of broken promises and unfairness'. By contrast, The Sun tended to agree that 'the pain has been spread fairly, with the better-off hit hard while those at the bottom are protected', and cited a YouGov poll according to which $57 \%$ of the respondents thought Osborne had made the right decision, with only $27 \%$ thinking the Budget was unfair. ${ }^{6}$

Appeals to fairness were used in very different ways: for some arguers, fairness genuinely informed action; for others, it manifestly did not but ought to have done. This is to say that the argument either did or did not pass the test of CQ3. In addition to challenging fairness as a genuine motive (CQ3), the austerity Budget was challenged in light of how its consequences would affect the government's institutional obligation to act fairly, in the process of weighing reasons (CQ5). According to the critics, fairness was being sacrificed in the process of pursuing the goals; this was advanced as a very strong argument against austerity by those who took the government's commitment to fairness to be non-overridable (an institutional constraint on action). More often, though, fairness was understood according to a meritocratic, 'desert' conception - one that accords with popular common sense - and not in relation to justice or equality. This may explain the general acceptance of cuts in the welfare budget on the strength of the argument (made by The Daily Telegraph, Daily Mail or The Sun) that welfare spending cuts have to be made for the sake of fairness: 'we must all bear our fair share of the burden of paying off the deficit', 'it is only fair the unions accept the need for efficiencies', and the 'state's disgraceful indulgence of welfare-guzzling layabouts' has to come to an end. This argument said that fairness was not being sacrificed, thanks to the government's efforts to 'spread the pain fairly', protect the worst-off, and demand more from those with the 'broadest shoulders'. Though rarely, the argument was also heard (in The Daily Telegraph) that fairness had to be sacrificed because there was no alternative. ${ }^{7}$

Questions 1-3 challenge the truth of the premises (indicating they may need revising) but leave the proposal (conclusion) itself intact: a satisfactory answer to these questions does not mean that the proposal itself is reasonable. By comparison, CQ4 and CQ5 can rebut the conclusion of the argument. CQ4 asks whether the stated goal (as intended consequence) is, on balance, acceptable, and CQ5 asks whether the side effects of the action (the unintended consequences) are, on balance, acceptable, as far as they can be foreseen, based on all the facts at the critics' disposal. Critical testing at this stage can yield critical objections that cannot be overridden, thus indicating that the proposal ought to be abandoned. Once a proposal is conclusively rejected, deliberating agents would need to return to the starting point and start testing another proposal (alternative).The question is: which considerations (reasons) can and ought to override others in evaluating a particular alternative? The political field, as an institutional order, is the realm of deontic reasons for action (Searle 2010) - rights, obligations, commitments, entitlements, 
authorizations, prohibitions. These function as external (desire-independent) constraints on action and cannot be easily overridden: political actors are expected to act in a certain way whether they want to or not (Fairclough \& Fairclough 2012, 2013).

Criticism of practical proposals on the grounds of their likely undesirable consequences (CQ4, CQ5) was widely used in the aftermath of the Budget speech. While some of the Chancellor's long-term stated goals (a 'fairer Britain ... where prosperity is shared among all sections of society and all parts of the country') were hard to challenge, critics of austerity called for a fundamental redefinition of what they saw as the immediate goals of action, for a new political vision. According to Caroline Lucas, instead of 'slashing public spending in the hope of resuming business as usual', the government should 'seize this opportunity to reconfigure the deeply unsustainable economic system which has helped push us towards financial meltdown' (Elliott 2011). If the goal was a return to business-as-usual, to the same system that had caused the crisis, as the 'soft touch approach to the City' (Elliott 2010b) seemed to indicate, then austerity was in need of radical transformation at the level of goals (i.e. it failed CQ4).

Regarding the unintended consequences (CQ5), opponents of austerity pointed to the likely catastrophic consequences of cutting expenditure too soon and too quickly, for example a surge in unemployment, particularly amongst young people. Not only would austerity fail to realize its own stated goals (because a combination of low growth in tax receipts and high growth in welfare spending would require more borrowing, which would only increase the existing debt), but it would clash with existing political commitments (institutional facts) - it would be unjust, it would damage lives - and therefore with concerns that the government was expected to have. In The Daily Telegraph, for example, Mary Riddell (2010) warned that 'the very fabric of society will be put at risk by this unfair Budget' and that 'directing savage spending cuts at the young is a dangerous course for any government to pursue', forcing them 'down the long road to perdition'. In turn, defenders of austerity pointed to the likely catastrophic consequences of failing to deal with the debt: loss of business confidence, a downgrade of Britain's credit rating, leading to higher interest rates, which would increase the existing debt. In both cases, the argument was that the anticipated consequences would undermine the government's stated goals (to reduce the debt) and other widely accepted, legitimate goals (keeping unemployment down, retaining business confidence), as well as going against a range of reasons which, depending on which conclusion was defended, were deemed to be in principle non-overridable: existing commitments to fairness or justice, to financial responsibility and the national interest. For example, in warning that '[the Liberal Democrats] pick up an axe that will inflict great pain on those they once vowed to protect', Freedland (2010a) was not only referring to potentially unacceptable consequences ('great pain') but also at the same time making it clear that, in his view, the promises that the Liberal Democrats had made during the electoral campaign gave them non-overridable deontic reasons for action which their current action placed them at odds with.

It is also possible to conclude that the potential side effects of a policy proposal would be in principle unacceptable, but do not constitute critical objections to it (i.e. the case for austerity stands in spite of counter-considerations). This could be for several reasons, all making implicit or explicit reference to a notion of strategy. It may be the case that an effective way of dealing with the side effects (should they arise) has already been identified: there is a 'Plan B' that the agent can switch over to, if faced with negative feedback. There may also be a broader strategy in place, involving actions whose role is to mitigate the negative effects of doing A. For example, while austerity is increasing unemployment, the government could be simultaneously engaging in a job- 
creation strategy; or while the state sector is being shrunk, the private sector could be encouraged to grow to compensate. It is also possible to reasonably persist in doing $A$ in the face of emerging negative feedback if it can be reasonably argued that more time is needed before the benefits begin to appear. On this view, the unacceptable side effects are outweighed by the long-term benefits, or are merely temporary, and the situation 'needs to get worse before getting better'. Finally, it is also possible to answer CQ5 in the negative and, although no 'Plan B' or mitigation strategy are in place, still decide to go ahead with $A$, thereby taking the risk of an unacceptable outcome. In this situation, there is a rationality deficit, and deciding to do $\mathrm{A}$ is similar to a gamble.

The critics and defenders of austerity exploited all these possibilities. Early in 2011, as austerity was already on its way, a fall in GDP for two consecutive quarters prompted the government's critics to call for a 'Plan B'. From a critical rationalist perspective, it is rational to take a negative outcome into account as a real possibility and prepare for it, not to have blind confidence in a positive outcome. The fact that the Chancellor did not seem willing to change course was taken by his critics as a failure of rationality. A Guardian editorial (Spending cuts, 2010) cited Osborne's reply to the Treasury select committee who had asked 'what his back-up plan actually was'. He said: 'The plan is to have confidence in the British economy', prompting the editor's comment that 'crossing one's fingers is not a plausible strategy for the man running the British economy'. The economic strategy was called into doubt by those who argued that the government was not sufficiently stimulating alternative sectors that could provide employment and growth, and was defended by those who argued that it was in fact creating favourable conditions for the private sector to compensate for public sector cuts, as well as mitigating the impact on the poor (e.g. taking more people out of taxation). Austerity was also defended in spite of the potential high costs, by seeing the costs as temporary and overridable in view of the benefits ('short-term pain for long-term gain', according to The Sun). 'If bitter deficit reduction medicine may push economically weak countries into recession, so be it', wrote Martin Feldstein (2010) in the Financial Times, and 'a double dip is a price worth paying', on balance, if this sets the UK on the path to stable recovery. Austerity was also seen as a dangerous 'gamble' (Wolf 2010a, Stephens 2010) - a serious challenge to the rationality of action, in view of the stakes involved. To conclude, defenders of austerity denied that, on balance, the potential consequences constituted critical objections against the strategy, either because spending cuts were allegedly part of a coherent strategy whose other components were designed to compensate, or because negative consequences could not be declared unacceptable within a short time frame, or because such consequences were essentially overridable in view of the goals and the even more serious consequences of not acting as proposed.

A proposal for action that undermines its own stated goals is clearly unreasonable in an instrumental sense (if not downright irrational). In the words of Larry Elliott (2010c) in The Guardian, 'Slash and burn is Osborne's cunning plan: Blackadder's Baldrick would be proud of the reasoning behind the austerity budget ... Like Baldrick, George Osborne has a cunning plan. It involves growing the economy through cuts'. This is to say that the chosen action will not achieve its goal because it is in principle impossible to achieve the goal by means of such action (the meansgoal premise is false, the argument fails CQ1), or that in the process of pursuing the goal, side effects are generated that undermine the possibility of achieving the goal (the proposal fails CQ5). From a non-instrumental perspective, one that evaluates the goals themselves, an action may be instrumentally adequate in view of its stated goal but may be wrong (unacceptable), either because the stated goal itself is unacceptable (the proposal fails CQ4) or because the action has unacceptable unintended consequences - for example, it clashes with other agents' legitimate 
goals, or goes against constraints on action (socially accepted values, institutional facts) which are arguably, on balance, non-overridable (it fails CQ5).

For example, according to Vince Cable, the way in which the financial crisis was dealt with, i.e. with 'the reckless and incompetent ... being rewarded, [and] the prudent and socially responsible punished', was 'a blow to the underlying value system, the social contract' (Cable 2009: 127-128). Similarly, for Martin Wolf, one aspect of the failure of the Western political elites to handle the crisis, which 'undermines the sense of fairness that underpins the political economy of capitalism', was their incapacity to prevent those 'parts of the elite most associated with the crisis [from becoming] richer than before' (Wolf 2014a: 352). The 2010 Budget was often criticized along these lines: making the poor pay for the crisis caused by the banks was fundamentally unjust (Milne 2010, Toynbee 2010), i.e. went against existing commitments and publicly recognized, legitimate values. It was also pointed out that the coalition government did not in fact have a democratic mandate for such an economic programme, i.e. there were legitimate non-overridable constraints on what the government was entitled or authorized to do. As such (deontic) reasons were not being taking into account, or were being overridden, the proposed action was arguably unreasonable (it failed CQ5).

Rejecting a proposal on the basis of unacceptable consequences will return the arguer to the starting point, where an alternative line of action should be chosen. In spite of the government's insistence that 'Labour's legacy of waste' made austerity unavoidable ('this is the unavoidable Budget', Osborne 2010), many arguably better means to deficit reduction were proposed from the start: structural economic reform, investment in green industries, a wholly new taxation system, including successfully pursuing tax evasion and tax avoidance (Elliott 2011). The 'necessary' (unavoidable) character of austerity was thus challenged: if there are alternatives, a proposal cannot be 'necessary'. In the Financial Times, Samuel Brittan (2010) asked: 'are these hardships necessary?'; 'the real argument... should be whether we need unparalleled fiscal austerity or not'. Similarly, Martin Wolf (2010a), calling the 2010 Budget 'savage', noted that 'the government must now win the argument that this tightening was essential'. The necessary character of austerity was by no means self-evident to him, in light of the alternatives available, e.g. continued borrowing, or a more 'aggressive monetary expansion' policy, only followed by contraction when growth has resumed (Wolf 2010b).

Finally, the last question (CQ6) cannot rebut the proposal but amounts to asking whether there are no other relevant facts about the context, which have not been taken into account, in light of which the conclusion does not follow (i.e. adding these facts to the premise set will invalidate or defeat the argument). For example, if there are facts about the context that make a proposal impossible to achieve, or if there are better means that have not been considered, then, however reasonable the proposal may be in principle, and even if it cannot be rebutted in light of its negative consequences, the argument in its favour will be defeated. It will not follow that the agent ought to do $A$, though neither will it follow that he ought not to do A. At this stage, critical questioning can help choose from a set of reasonable alternatives that have survived criticism in light of their intended and unintended consequences - a proposal which is more easily feasible or preferable in the context. For example, without objecting to the reasonableness of austerity, Jeremy Warner asked in The Daily Telegraph whether it would be possible to implement it in the context: 'The other main risk is that the spending cuts envisaged simply won't be achievable, involving as they do a complete reversal of the public sector expansion that took place under the last Government. (...) Mr Osborne can talk tough, but can he execute?' (Warner 2010a). This suggested a negative answer to CQ6. This 
last question is designed to choose, from among reasonable and contextually feasible alternatives, a comparatively better alternative, one that best corresponds to a particular agent's de facto overriding concerns. For example, the Chancellor defended a particular distribution of the financial consolidation: $80 \%$ of the savings were to come from spending cuts, while $20 \%$ from tax rises. It can be argued, even by defenders of austerity, that this ratio could have been different, while still being reasonable from the government's point of view. In the context, however, the 80:20 split was justified by a de facto concern for increasing Britain's attractiveness for business, which this particular split would presumably achieve more efficiently than others.

How have these arguments fared since 2010? Following a return to growth in 2014, the government took credit for having set the country on the road to recovery, and Britain's recession was officially declared over in July 2014. Together with a record fall in unemployment (under 2 million, i.e. pre-crisis levels, in October 2014), the recovery seemed to refute the critics' objections and provide conclusive evidence that the government's plan was working. However, according to some critics the 'wrong kind of recovery' is currently taking place, an 'unbalanced' one, dominated by the service industries (including the financial sector), by consumer spending and the housing market, not by manufacturing (Vince Cable, cited in Wintour et al 2014). Moreover, the return to growth is not being translated into increases in wages: a 'jobs-rich but pay-poor recovery', according to a Bank of England chief economist, where many jobs are only part-time, on 'zero-hour contracts', or poorly paid. Although the Budget deficit decreased between 2010-2012, it is still high, while the UK national debt has grown every year, thus clearly defeating the George Osborne's (2010) targets of having 'a balanced budget and falling national debt by the end of this Parliament', i.e. 2015. The argument has also been made (by Elliott 2015 and others) that the Chancellor in fact abandoned his original Plan A sometime in 2012 and reverted to the plans inherited from the Labour Chancellor, Alistair Darling, hence the incipient recovery.

For political scientist Mark Blyth (2013), 'austerity doesn't work'. There are no genuine cases of expansionary fiscal contraction in periods of economic slump, and austerity will always make the debt bigger, not smaller, as historical evidence shows. In his view, there was nothing inevitable about austerity, there were alternatives. One, preferable in retrospect, would have been not to bail out the banks. A solution now would be a renewed effort to collect taxes on a global scale - taxing the rich and the banks, the beneficiaries of the bailout (Blyth 2013: 229-244).

\section{Framing austerity: negative consequences as salient premises}

In this section I will draw selectively on work in progress on the corpus, focusing on just a few keywords and their associated semantic fields. ${ }^{8}$ My primary purpose is to suggest an argumentative conception of 'framing' and illustrate how analysis of framing can be integrated with the analysis and evaluation of argumentation.

The concept of 'framing' is widely used in political communication and media studies, as well as in cognitive linguistics, psychology, sociology and anthropology. There is little consensus on how to define and operationalize 'frames' (Entman 1993, Reese et al 2007, D'Angelo \& Kuypers 2010), yet there is some consensus that exposure to alternative arguments in public deliberation can weaken 'framing effects', the cognitive or decision bias induced by alternative ways of 'framing' an issue (Sniderman \& Theriault 2004). 
In another paper, I have proposed an argumentative definition of framing that is compatible with Entman's (1993) classic definition of framing in terms of 'selection and salience' ${ }^{9}$. Not all framing occurs within deliberative, decision-making processes (there is, for example, narrative framing, underlain by a different genre). When decision-making is involved, however, framing can be viewed as the selective salience given to certain premises in a deliberative process, intended to direct an audience towards a particular conclusion (and potentially towards a particular decision and course of action). Any practical reasoning premise (goals, values, consequences, circumstances, meansgoals relations) can be made selectively more salient in the attempt to direct the audience towards a preferred conclusion. The practical claim (proposal) itself can be made more salient by redefining it in a way that suggests it either should or should not be adopted. In this process, metaphors, analogies and 'persuasive definitions' (i.e. rhetorically biased definitions, Walton 2007a) may be used to redefine facts in rhetorically convenient ways and thus lend support either to the practical claim that A should be performed or that it should not.

The way in which the financial crisis was 'framed', for example, as a crisis of overspending (by making salient the alleged explanation for the circumstances) supported a particular solution: spending cuts. Similarly, the Chancellor's comparison between the UK economy and that of a household (making salient a particular definition of the circumstances of action) argued in favour of clearing debts as solution. Successful challenges of such definitions, metaphors and analogies can defeat the arguments in which they function as premises. National economies, for example, are not really similar to households. For a family or individual business it makes sense to cut costs, but if national economies try to cut costs, this will shrink demand and damage growth. In other words, 'an individual may not spend all his income. But the world must do so' (Wolf 2008).

While the primary mechanism of framing, on this account, involves making a particular premise more salient and potentially overriding, a second, additional mechanism seems to be at work whenever framing involves metaphors $(X$ is $Y$ ), analogies ( $X$ is like $Y$ ) or persuasive definitions ( $X$ is a kind of $Y$ ). In such cases, two frames, corresponding to the target and source domains, are mapped onto one another, so that the entailments of the source domain can be used to reason about the target domain (Fairclough \& Mădroane forthcoming). This section illustrates the first mechanism, the next one illustrates the second. ${ }^{10}$

One way of making the negative consequences salient in the austerity debate was in (nonmetaphorical) terms of 'risk' (a total of 217 relevant occurrences) (Table 2). The 'risks' of a 'doubledip recession' (58 occurrences), of 'choking off the recovery' (7) or of 'stagnation' (9) are potential consequences that need to be averted and result from various probability judgments based on known facts. For the defenders of austerity, failing to deal with the deficit is the main source of risk: Britain may lose fiscal credibility, which can lead to a downgrade in credit rating, hence to spiralling borrowing costs, a fall in investor confidence, and so on. Austerity will actually reduce risk: 'the economic gamble is much exaggerated', 'the cuts aren't that deep' and their effect is to reduce the 'possibility [of a fiscal crisis] from probable to most unlikely' (Warner 2010b, Daily Telegraph). For the critics, the austerity agenda itself is the source of risk. In particular, high risk arises from proposed action that is not accompanied by a 'Plan B' and seems immune to falsification in light of available knowledge (knowledge about past crises, economic theory) which should be used to test its reasonableness. There are 15 occurrences of 'Plan B' in the corpus, e.g. 'What's the plan B if the cunning plan goes wrong? The answer is simple: there is no plan B because the Treasury believes 
the need for one will not arise' (The Guardian). For some critics, this makes the risks unacceptable ('Overzealous cuts risk a double-dip recession and will fall disproportionately on the small people', Financial Times); for others, the risks are outweighed by the fact that any alternative would be worse ('There is a perfectly reasonable justification for taking this sort of risk: the alternative - a failing to tackle the deficit - is even more dangerous', The Daily Telegraph).

\begin{tabular}{|c|c|c|}
\hline Newspaper & Risk* & Examples \\
\hline The Guardian & 72 & $\begin{array}{l}\text { 'George Osborne's austerity budget has increased the risk of } \\
\text { Britain sliding back into recession'; 'the risk is you derail the } \\
\text { recovery and that means your borrowing in the longer term } \\
\text { will be higher' }\end{array}$ \\
\hline $\begin{array}{l}\text { The Daily } \\
\text { Telegraph }\end{array}$ & 40 & $\begin{array}{l}\text { 'The Liberal Democrats now agree with the Conservatives } \\
\text { that the balance of risk favours early action'; 'Britain } \\
\text { remains at risk of a rating downgrade'; 'this Budget risks } \\
\text { tearing society apart' }\end{array}$ \\
\hline The Daily Mail & 30 & $\begin{array}{l}\text { 'Britain is so far into the red that we risk losing the } \\
\text { confidence of the financial markets'; 'the scale of the } \\
\text { budget deficit risks causing a major crisis in our economy'; } \\
\text { 'Osborne is risking a double-dip recession' }\end{array}$ \\
\hline Financial Times & 70 & $\begin{array}{l}\text { 'There is a risk that synchronised fiscal adjustment across } \\
\text { several major economies could adversely impact the } \\
\text { recovery'; 'Fiscal consolidation will bring with it the risk of a } \\
\text { temporary decline in economic activity and a rise in } \\
\text { unemployment'; 'the risk of a second Great Depression' }\end{array}$ \\
\hline The Sun & 5 & '[Labour warned that the Budget] would put recovery at risk' \\
\hline
\end{tabular}

Table 2. Negative consequences as 'risks'

Besides emphasizing negative consequences as serious risks, usually seen as critical objections against the proposed action, a variety of metaphors were used to strengthen the case for or against austerity, by lending support to the claim that the consequences were, on balance, acceptable or not. I will now turn to a few cases of such metaphorical framing. ${ }^{11}$

\section{The argumentative function of metaphors in framing the austerity debate}

Austerity as policy proposal was 'framed' in various ways. A particularly striking definition was that of the June 2010 Budget as a 'gamble' (43 relevant occurrences in the corpus). According to The Guardian, Osborne's Budget was 'in reality ... the budget of a gambler', 'a gamble on a monumental scale', 'a gamble with the livelihoods and living standards of millions of people' (21 occurrences). Readers were told that 'Osborne has gambled that early toughness will yield later peace' and 'if 
Osborne's gamble pays off, it is Thatcherism's finest hour'. In addition, the policy was described as 'deficit-slashing superstition' and 'deficit fetishism', suggesting a deficit of rationality and irrational risk-taking and lending argumentative support to the conclusion that austerity is not the right policy. According to the Financial Times, 'this gamble has now defined the government. If it is seen to have failed, it will be finished'. ('Gamble' occurs 10, 4, 6 and 2 times in the Financial Times, Daily Telegraph, Daily Mail and Sun, respectively.) The Budget was also said to be a 'bet' ( 9 occurrences in the corpus): 'Mr Osborne is taking a big bet that the economy will come right through market forces ... and he does not have a safety net in case his bet sours'; 'all is bet on the heroic assumption that the economy comes good, growth is miraculously quick and the pain was worth it'. If austerity is a gamble, then by entailment ${ }^{12}$ it involves unjustifiable, even irrational risk. This feeds into an argument against austerity: because austerity is similar to a gamble, the potential consequences are unacceptable and the proposal fails to survive CQ5 (the outcome could be disastrous and there is no way of mitigating or redressing it).

In addition to metaphors suggesting extreme reckless or irrational behaviour ('gambling', but also 'lunacy': 'the lunatics are back in charge of the economy and they want cuts, cuts, cuts', Elliott 2010a), metaphors suggesting extreme violence towards the population seem to predominate in framing austerity policies. For example, there are over 83 occurrences of 'axe' in the corpus: 'axing spending', 'where the axe will fall', a 'repeat of the heartless axe-wielding of the Thatcher years', 'some Lib Dem yellow ribbons decorated the handle of the axe, but they barely impeded the swing of the executioner's arm', 'the axe-man' [i.e. Osborne]. The Budget is also described as an 'assault' ('the biggest sustained assault on the public sector since the war'), an 'attack' ('attacks on public services, pay and pensions'), a 'war' ('an ideological war against the public sector'), a 'slash-andburn' approach. In the Financial Times, Martin Wolf (2010a) uses 'bloodbath' as a metaphor for the Budget ('this was a bloodbath none was prepared for'); there are 14 occurrences of 'bloodbath' in total.

Other metaphors support the opposite conclusion. Framing the Budget as 'surgery' (The Daily Telegraph: 'painful surgery', 'the surgeon-Chancellor was gentler than many expected') suggests that it will restore Britain's economy to health (will have positive consequences), and therefore austerity is, on balance, the right policy. Surprisingly, defining austerity as a bloodbath sometimes supports the same conclusion in favour of austerity. In an article entitled 'Britons Back Tough George', The Sun claimed that 'George Osborne's bloodbath Budget is a shock hit with voters'. This reflects a particular way of weighing reasons, in which the impact of austerity is outweighed by its alleged benefits.

Framing austerity as a 'gamble' (or as 'surgery' or 'execution') achieves two things: 1 ) it maps two frames onto one another, i.e. the POLICY frame is mapped onto the GAMBLE frame, and the entailments of the latter are then used to reason about the former; $(2)$ it gives prominence to a particular premise within the deliberation scheme (in this case, a premise within the argument from negative consequence) so as to direct the audience towards a particular conclusion. If austerity is adopted, then the consequences (i.e. very high risks) will be unacceptable, because the policy is similar to a gamble; therefore (unless these potential consequences can be overridden) it follows that the policy should not be adopted. ${ }^{13}$

Figure 2 suggests where such metaphors or definitions are embedded in the overall argument ('austerity as a gamble' or 'bloodbath' in the argument from negative consequence on the left, and 'austerity as surgery' in the argument from positive consequence on the right). 


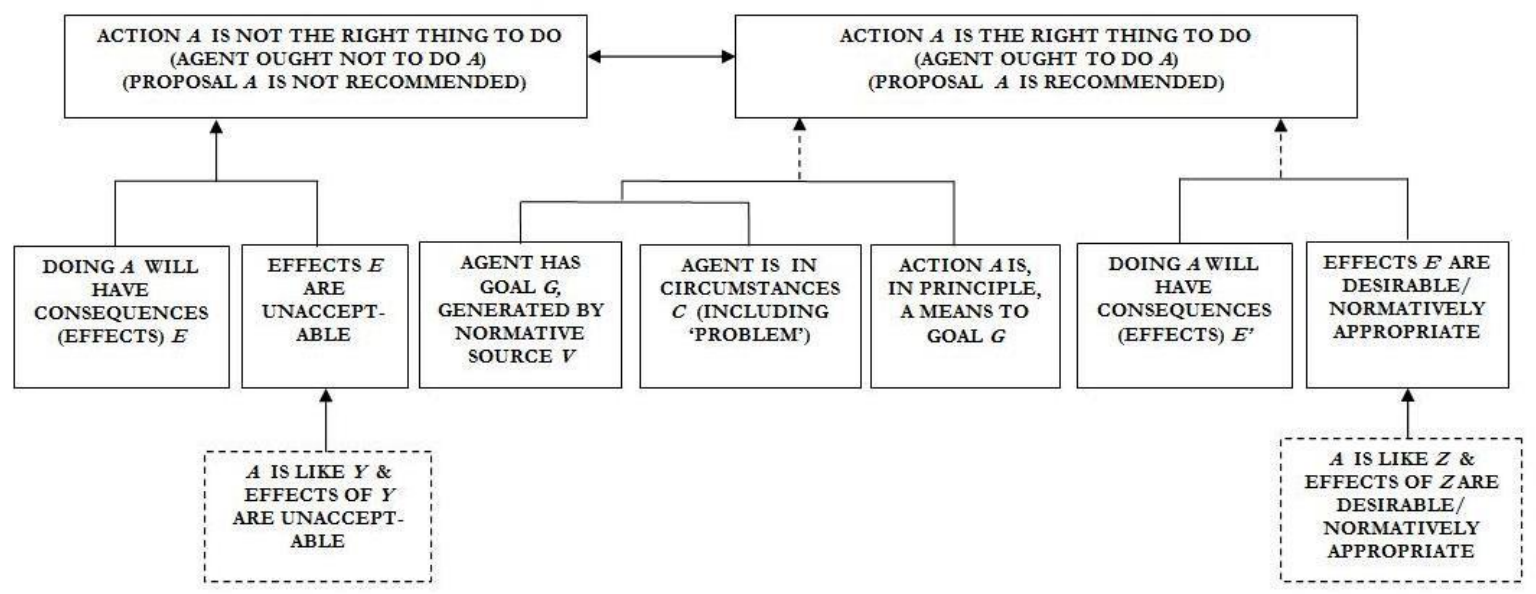

Figure 2. The argumentative function of metaphors, analogies and persuasive definitions

The consequences of austerity are also frequently expressed in metaphorical terms of 'pain' (Table 3 ), part of the wider framing of austerity in terms of metaphors of violence. The Guardian speaks about 'the unjust distribution of pain', generally questioning the claim that 'the rich will feel more pain than the poor' or that 'the pain would be borne equally' and warning that that 'the pain will fall on the poorest people in the poorest regions'. The Daily Mail argued that 'Without pain, there will be no recovery' and the 'Budget pain can make Britain stronger' (headlines), that the 'painful Budget' was 'unavoidable if Britain is to prevent the money markets imposing a Greek-style crisis on this country'. This suggests that the potential negative consequences have been weighed against other reasons in favour and have been overridden: pain is necessary and unavoidable if the goals are to be achieved and even more serious consequences are to be avoided. Similarly, The Daily Telegraph claimed that 'some pain today would avoid more pain tomorrow' and 'to be radical, in the current situation, means to perform painful but life-saving surgery on the British economy', i.e. alternatives to 'pain' are worse ('pain' is overridden or outweighed).

\begin{tabular}{lll}
\hline \hline Newspaper & Pain* & Examples \\
\hline \hline The Guardian & $\mathbf{4 7}$ & $\begin{array}{l}\text { 'Pain now, more pain later'; the 'debatable claim' that 'the } \\
\text { rich will feel more pain than the poor'; 'the unjust } \\
\text { distribution of pain'; , 'unnecessary pain', 'severe pain', } \\
\text { 'painful spending cuts' }\end{array}$ \\
\hline \hline $\begin{array}{l}\text { The Daily } \\
\text { Telegraph }\end{array}$ & $\mathbf{2 8}$ & $\begin{array}{l}\text { The Chancellor 'delivered the bad news about painful } \\
\text { surgery'; 'everyone had to share the pain to repair the } \\
\text { ruins of the economy'; 'the pain has been spread } \\
\text { proportionately' }\end{array}$ \\
\hline \hline The Daily Mail & $\mathbf{4 4}$ & $\begin{array}{l}\text { 'painful public spending cuts'; 'a Parliament of pain'; } \\
\text { 'making sure that the pain will be evenly shared between } \\
\text { rich and poor'; 'ease the pain of a bloodbath package' }\end{array}$ \\
\hline \hline
\end{tabular}




\begin{tabular}{lll}
\hline \hline Financial Times & 35 & $\begin{array}{l}\text { 'Mr Osborne believes the fiscal pain now will pave the way } \\
\text { for recovery'; 'for all that the government claims it wants } \\
\text { the pain to be evenly spread, the less well-off and the } \\
\text { poorest regions will suffer most'; 'a painful Budget' }\end{array}$ \\
\hline \hline The Sun 35 & $\begin{array}{l}\text { 'Worth the Pain'; 'Pain today rather than more pain } \\
\text { tomorrow'; 'Britain braces itself for five years of pain'; } \\
\text { 'George Osborne vowed to ease the pain of cuts'; 'his } \\
\text { painful national belt-tightening was right'; 'painful but } \\
\text { unavoidable job losses' }\end{array}$ \\
\hline \hline
\end{tabular}

Table 3. Negative consequences as 'pain'

To a much greater extent than the other newspapers, The Sun viewed pain as a necessary consequence, and one that was overridden by other reasons. As the headline: 'Worth the Pain. Tough measures get thumbs-up' suggested, the benefits of austerity were worth the suffering. 'If, out of the ashes of Labour, Mr Osborne creates a self-reliant nation freed from the shackles of benefit addiction, he will have ensured yesterday's pain was not in vain'. According to The Sun, the Budget 'has to hurt', and it 'has to be so tough it brings tears to our eyes'. Thus, a late-June Yougov poll allegedly showed that Britons gave the Chancellor a 'vote of confidence' and indicated 'strong support for many of the other pain doses', particularly the cap on housing benefits (with $70 \%$ in favour). In addition, austerity's effects on the poor had allegedly been carefully mitigated: 'the pain has been spread fairly, with the better-off hit hard while those at the bottom are protected'; 'like a dentist with a pain-killing injection, Mr Osborne will ease the misery by taking nearly a million low paid workers out of income tax altogether'. Austerity cannot therefore be faulted and successfully survives critical questioning in light of its consequences (withstands both CQ4 and CQ5).

The way in which the 'pain' metaphor is used in the 5 newspapers is apparently similar (similar collocations: 'spread the pain', 'inflict pain', 'ease the pain', 'share the pain') but, from an argumentative perspective, very different. Almost without exception, The Guardian talks about 'pain' as an unacceptable consequence that ought not to be overridden by other reasons (i.e. the goal does not justify the means). At the other end of the spectrum, again almost without exception, The Sun predominantly views pain as fundamentally overridable concern, in light of the greater benefits to be obtained and of the efforts being made to mitigate or 'ease the burden' on the population. Two fundamentally different arguments are being made in these articles. One is an attempt to conclusively reject austerity, on the grounds of failing CQ5, admitting it has survived CQ4. The other supports it, for allegedly answering both CQ4 and CQ5 in a satisfactory manner: the negative consequences do not, on balance, constitute critical objections, in light of mitigation strategies in place and because they are outweighed by greater benefits.

To conclude, negative consequences (as premises) were made more salient (and thus presumably expected to direct the audience towards a particular view of austerity) either with or without the help of underlying metaphors, analogies or persuasive definitions. In both cases, the framing process was accompanied by a weighing of reasons (the essence of deliberation). In some cases, the negative consequences were deemed to be on balance unacceptable, thus indicating that austerity was not a reasonable policy and ought to be abandoned; in others, they were allegedly overridden or outweighed by other premises and did not succeed in rebutting the conclusion. 
Rhetorically powerful metaphors (austerity as 'gamble' or 'bloodbath') were used by the critics of austerity to persuade audiences that the consequences should on balance be viewed as unacceptable, that they cannot overridden by any other reasons (i.e. they are critical objections), and thus to direct the audience towards rejecting austerity.

\section{Conclusion}

I have illustrated the way in which the austerity policies initiated by the UK government in 2010 were evaluated in a range of newspapers in the two months that followed the 2010 Emergency Budget. In proposing a deliberation scheme and set of critical questions, I have tried to offer a means of analyzing and evaluating any deliberative activity type that ends in a practical proposal for action. My main purpose was to offer a framework for analysis and evaluation, usable primarily by policy and discourse analysts, but also potentially by policy-makers, political activists, journalists and other actors in the political field. I have also shown how 'framing', which is only vaguely, if at all, related to analysis of argumentation in the literature, is best seen as contributing premises in a deliberative and decision-making process and thus shaping the inferential process towards a particular conclusion.

I have drawn (admittedly, to a limited extent) on Corpus Linguistics methods in order to analyze concordance lines and keywords, but I have done so primarily in order to facilitate analysis of argumentation. I have placed keywords within argument schemes, in the premises and conclusions of arguments. The analysis has shown not only that there is no straightforward correspondence between the concept of consequence and its linguistic realizations, but that one needs to have a concept of consequence first, as a premise in an argument scheme, and an understanding of what the public debate is about, in order to start looking for the linguistic realization of this premise with the help of computer software. It has also shown that the same reasons (premises) are weighed differently by different arguers, leading to different conclusions. Generalizations about the way different newspapers position themselves in relation to austerity are thus impossible to make on the basis of judgments of keyness alone: the arguments themselves must be carefully unpacked.

The austerity agenda has been criticized by economists, political scientists and NGOs (NEF, Compass, Tax Research UK, etc.). However, apart from the Occupy movement and a number of other protests and strikes, austerity has not been challenged significantly by the broad UK public. This may be due in part to the way in which, in framing the crisis as one of state overspending, the government has successfully enlisted common sense on its side: a common sense view of the economy (a 'household' that must pay off its debts and 'live within its means'), of acceptable solutions ('no pain, no gain', 'you cannot cure debt with more debt') and of fairness (it is not fair that working people should support people who choose to live on benefits). It has also been suggested that, by activating a 'logic of resentment', and 'drawing a line of antagonism' between 'hard-working' people and 'scroungers' or 'skivers', the government has managed to create a broad acceptance of the austerity agenda by the population, in spite of its harsh impact (Seymour 2017: 158). Possibly, another cause is the failure of the main parliamentary opposition, Labour, to develop a real alternative to austerity.

All of the arguments for and against austerity that are being heard at the end of 2014 were already present in the public debate on austerity that took place in the summer of 2010. Neither the supporters nor the critics of austerity seem at the moment willing to withdraw their original 
arguments in the face of emerging evidence, which continues to be interpreted in ways that support their original standpoints. For the Chancellor, a return to growth and high employment figures indicate that austerity is working. For his opponents, austerity's clear failure to reduce the debt and the weakness of the recovery indicate it ought to be abandoned. Not only have the intended goals not been achieved (instead, what high-income countries are now experiencing is a 'truly extraordinary state of managed depression', according to Wolf 2014b), but the impact on other legitimate goals (living standards, in the UK and throughout Europe) has been severe, hence some alternative arguably has to be found. It may be that, as Blyth (2013: 244) argues (in defending taxation as a reasonable solution), austerity will be abandoned eventually, though 'not because [it] is unfair, which it is', but primarily because, from a purely instrumental perspective, 'austerity simply does not work'.

\section{References}

Anthony, L. (2014). AntConc (Version 3.4.3w) [Computer Software]. Tokyo, Japan: Waseda University. Available from http://www.antlab.sci.waseda.ac.jp/.

Audi, R. (2006). Practical Reasoning and Ethical Decision. London: Routledge.

Blyth, M. (2013). Austerity. The History of a Dangerous Idea. Oxford: Oxford University Press.

Brittan, S. (2010, June 18). Are these hardships necessary? Financial Times. Retrieved from: www.ft.com.

Cable, V. (2009). The Storm. The Word Economic Crisis and What it Means, London: Atlantic Books.

D'Angelo, P., \& Kuypers, J. A. (Eds.) (2010). Doing News Framing Analysis. Empirical and Theoretical Perspectives. New York: Routledge.

DeLong, B. (2010, July 23). Trichet rejects the counsel of history. Financial Times. Retrieved from: www.ft.com.

Eemeren, F. H., van (2010). Strategic Maneuvering in Argumentative Discourse, Amsterdam: John Benjamins.

El-Erian, M. (2010, June 24). Beyond the false growth vs austerity debate. Financial Times. Retrieved from: www.ft.com.

Elliott, L. (2010a, June 14). UK economy: The deficit hawks need their talons clipped: Sadly, the Lib Dems are unwilling to challenge these cuts that risk returning us to recession-or worse. The Guardian, p. 26.

Elliott, L. (2010b, June 22). Budget 2010: The axeman cometh, The Guardian. Retrieved from: www.theguardian.com.

Elliott, L. (2010c, July 19). Slash and burn is Osborne's cunning plan: Blackadder's Baldrick would be proud of the reasoning behind the austerity budget. The Guardian, p. 22.

Elliott, L. (2011, January 25). Britain's shrinking economy: panel verdict, The Guardian. Retrieved from: www.theguardian.com.

Elliott, L. (2015, February 15). Labour must push what Milliband has got right on the economy in election runup. The Guardian. Retrieved from www.theguardian.com.

Entman, R. M. (1993). Framing: Toward clarification of a fractured paradigm. Journal of Communication 43(4), 51-58. 
Fairclough, I., \& Fairclough, N. (2011). Practical reasoning in political discourse: the UK government's response to the economic crisis in the 2008 Pre-Budget Report. Discourse \& Society, 22(3), 243-268.

Fairclough, I., \& Fairclough, N. (2013). Argument, Deliberation, Dialectic and the Nature of the Political: A CDA Perspective. Political Studies Review , 11(3), 336-344.

Fairclough, I., \& Fairclough, N. (2012). Political Discourse Analysis. London: Routledge.

Fairclough, I., \& Mădroane, I. D. (forthcoming). An argumentative approach to policy "framing". Competing "frames" and policy conflict in the Roşia Montană case. In Garssen, B. \& A. F. Snoeck Henkemans (Eds.), Proceedings of the 8th Conference of the International Society for the Study of Argumentation. Amsterdam: SicSat.

Fairclough, N. (2014). Language and power (third edition), London: Routledge

Feldstein, M. (2010, July 22). A double dip is a price worth paying, Financial Times, online edition, www.ft.com.

Ferguson, N. (2010, July 19). Today's Keynesians have learnt nothing. Financial Times. Retrieved from: www.ft.com.

Fillmore, C. J., \& Atkins, B. T. (1992). Toward a frame-based lexicon: The Semantics of Risk and its neighbours. In A. Lehrer \& E. F. Kittay (Eds.), Frames, fields, and contrasts: New essays in semantic and lexical organization (pp. 75-102). Mahwah, NJ: Erlbaum.

Fischer, F., \& Gottweis, H. (Eds.) (2012). The Argumentative Turn Revisited. Durham and London: Duke University Press.

Freedland, J. (2010a, June 23). Rooted in deficit-slashing superstition, this budget will hit the poor hardest. The Guardian, p. 31.

Freedland, J. (2010b, October 20). Osborne will escape public wrath if Labour lets him win the blame game. The Guardian, p. 31.

Keynes, J. M. (1971-89). XIV: The general theory and after: part II, in The Collected Writings, volumes I to XXX. London: Macmilllan \& Cambridge University Press for the Royal Economics Society.

Krugman, P. (2010a, July 2). Myths of austerity. The New York Times. Retrieved from: www.nytimes.com.

Krugman, P. (2010b, October 21). British Fashion Victims, The New York Times. Retrieved from: www.nytimes.com.

Miller, D. (1994). Critical Rationalism: A Restatement and Defence. Chicago: Open Court.

Miller, D. (forthcoming). Deductivist Decision Making, unpublished MS.

Milne, S. (2010, June 24). Budget 2010: Osborne's claims of fairness are now exposed as a fraud. The Guardian, p. 33.

Monson, G., \& Subramaniam, S. (2010, July 27). Austerity drives can unleash confidence. Financial Times. Retrieved from: www.ft.com.

Osborne, G. (2010). 2010 Budget - Responsibility, freedom, fairness: a five year plan to re-build the economy. HM Treasury. Retrieved from http://webarchive.nationalarchives.gov.uk/20130129110402/http:/www.hmtreasury.gov.uk/2010_june_budget.htm.

Parsons, W. (2012). Keynes and the utility of policy-relevant knowledge. Critical Policy Studies, 6(3), 223-242. DOI: 10.1080/19460171.2012.704978.

Randall, J. (2010, June 18). Budget 2010: The days of spend now and pay back later are over. Later is now. The Daily Telegraph, p. 28.

Reese, S. D., Gandi, S. D., \& Grant, A. E. (Eds.) (2007). Framing Public Life: Perspectives on Media and Our Understanding of the Social World. Mahwah, NJ: Erlbaum. 
Riddell, M. (2010, June 22). Budget 2010: The very fabric of society will be put at risk by this unfair Budget. The Daily Telegraph, p. 20.

Sachs, J. (2010, July 21). Sow the seeds of long-term growth. Financial Times. Retrieved from: www.ft.com.

Searle, J. R. (2010). Making the Social World. The Structure of Human Civilization, Oxford: Oxford University Press.

Seymour, R. (2014). Against Austerity, London: Pluto Press.

Skidelsky, R., \& Kennedy, M. (2010, July 27). Future generations will curse us for cutting in a slump. Financial Times. Retrieved from: www.ft.com.

Sniderman, P. M., \& Theriault, S. M. (2004). The Structure of political argument and the logic of issue framing. In P. M. Sniderman \& W. E. Saris (Eds.), Studies in public opinion: Attitudes, nonattitudes, measurements, error and change (pp. 133-155). Princeton: Princeton University Press.

Spending cuts: No way to run an economy (2010, July 21). The Guardian, p. 30.

Stephens, P. (2010, June 22). True-blue cuts will test the coalition. Financial Times. Retrieved from: www.ft.com.

The Sun says: Owed Labour (2010, June 22). The Sun, p. 8.

Toynbee, P. (2010, June 23). Lib Dem ribbons decorated the axe - but didn't impede the executioner. The Guardian, p. 1.

Walton, D. (2006). Fundamentals of Critical Argumentation. New York: Cambridge University Press.

Walton, D. (2007a). Media Argumentation. New York: Cambridge University Press.

Walton, D. (2007b). Evaluating practical reasoning. Synthese, 157, 197-240.

Warner, J. (2010a, August 14). Osborne hit the ground running, but can he stay the distance? The Daily Telegraph, p. 20.

Warner, J. (2010b, June 24). Get a sense of proportion - the cuts aren't that deep, The Daily Telegraph, p. 5.

Wintour, P., Elliott, L., \& Allen, K. (2014, January 28). Vince Cable undermines chancellor with 'wrong sort of recovery' message. The Guardian, p. 2.

Wolf, M. (2008, December 23). Keynes offers us the best way to think about the financial crisis. Financial Times. Retrieved from www.ft.com.

Wolf, M. (2010a, June 22). A bloodbath none was prepared for. Financial Times. Retrieved from: www.ft.com.

Wolf, M. (2010b, June 23). Why it is right for central banks to keep printing. Financial Times. Retrieved from: www.ft.com.

Wolf, M. (2014a). The Shifts and the Shocks. London: Allen Lane.

Wolf, M. (2014b, October 9). An extraordinary state of 'managed depression'. Financial Times. Retrieved from: www.ft.com.

Biographical note

Isabela Fairclough is Senior Lecturer at the University of Central Lancashire. Her publications focus on the critical analysis of political discourse from the perspective of argumentation theory and include the monograph Political Discourse Analysis (Routledge 2012, with Norman Fairclough), as well as research on transition to liberalism and a market economy in Eastern Europe. 


\section{Notes}

${ }^{1}$ This paper started as a keynote at a conference entitled The Discourse of Austerity: Critical analyses of business and economics across disciplines, hosted by Newcastle University in September 2013. I am grateful to the conference organizers and participants, particularly to Darren Kelsey and Majid KhosraviNik, as well as to David Miller, Norman Fairclough, Sheryl Prentice and two anonymous reviewers for valuable comments and suggestions.

2 These were selected with the help of LexisNexis database (except for the Financial Times), using 'Budget' and 'Osborne' or 'cut*' as search terms, from a total of 973 articles (in all UK national newspapers). This corpus was then restricted to four national newspapers (461 articles). The Financial Times corpus was compiled separately, using two separate searches in the $F T$ archive, one amongst 'articles', using the predefined search terms 'United Kingdom', 'George Osborne' and the relevant time period, and another one with 'cut*' and 'austerity', to select other pieces which were not classified as 'articles', e.g. the July 2010 'Austerity Debate'. These two searches yielded a total of 92 articles between the same dates. The analysis was assisted by Antconc, a Corpus Linguistics software (Anthony 2014).

${ }^{3}$ Argument schemes are basic patterns of human reasoning, empirically-derived inferential structures that underlie everyday argumentation. Their structure creates possibilities for critical questioning, in the form of finite sets of critical questions attached to each scheme. These may be actually asked by participants in everyday argumentation or they may not. It is the task of the analyst to bring the normative template of the deliberation scheme to bear on the systematic evaluation of public debate, by asking all the relevant questions that the template makes possible (normative critique), as well as inquiring into why some of these questions are either not asked or answered in a satisfactory manner, if that is the case (explanatory critique). For the distinction between normative and explanatory critique, see the Introduction to Fairclough 2014.

${ }^{4}$ There does not seem to be a way of ordering CQ1-CQ3 among themselves; however, CQ4-CQ6 do enable a progressive narrowing down of alternatives.

${ }^{5}$ According to Blyth, the 'opportunistic rebranding' of private-sector debt as public debt and the attribution of its causes to excessive public spending was 'the greatest bait and switch in modern history'. The correct explanation was this: 'Bailing led to debts. Debt led to crisis. Crisis led to austerity' (Blyth 2013: 73, 231).

$6 *$ Fair* (fair, fairness, unfair, etc.) is one of the main keywords; there are 99 relevant occurrences of *fair* in The Guardian, 59 in The Daily Telegraph, 31 in The Daily Mail, 31 in the Financial Times and 29 in The Sun. 'Progressive' (68 occurrences) and 'regressive' (32 occurrences) are used similarly.

${ }^{7}$ A concern for fairness is an internal reason, a motive for action. A commitment to fairness, creating an obligation to be fair, is an external reason (part of the circumstances of action, as an institutional constraint) that ought to motivate agents, although it does not always do so. External reasons may be internalized, turned into motives or not, but agents continue to have them as reasons, even when they do not act on them (obligations do not disappear just because we choose to ignore them) (Fairclough \& Fairclough 2012: 69-73, see Searle 2010).

${ }^{8}$ The lexical items I am looking at (*fair*, pain*, risk*, hit*, ax*, gambl* and bloodbath) all occur with the first 500 keywords of the corpus (out of 8777) and have very high keyness values. Judgements of keyness initially emerged from reading a smaller version of the corpus ( 250 texts, 50 for each newspaper) in its entirety; these initial impressions were then tested by comparing the keyword list with the Brown corpus keyword list, available on the Antconc website, which was used as reference. 
9 'To frame is to select some aspects of a perceived reality and make them more salient in a communicating text, in such a way as to promote a particular problem definition, causal interpretation, moral evaluation, and/or treatment recommendation for the item described' (Entman 1993: 52).

${ }^{10} \mathrm{I}$ am proposing a new view of the framing process, not of frames. Regarding frames, I take the Fillmorian view that they are systems of related concepts - e.g. the RISK frame (Fillmore \& Atkins 1992), involving an agent, a proposed action, potential harm, intended gains, etc. The argumentative scheme for deliberation can be used to define a DECISION-MAKING frame in Fillmorian terms, involving an agent proposing a course of action amongst possible alternatives, in view of certain goals and values, with potential consequences.

${ }^{11}$ In the corpus, negative consequences are expressed in both metaphorical and non-metaphorical terms, e.g. by verbs like 'suffer' or 'hit' and nouns like 'impact', 'effect', 'consequence', 'burden'. There are 290 relevant occurrences of 'hit*' ('[The Budget will] hit the poorest hardest, while barely inconveniencing the rich') and 68 of 'suffer' ('the poor will suffer the most from the budget').

${ }^{12}$ Entailment is a logical relation between sentences, where the truth of one requires the truth of the other: if something is a gamble, then it is risky.

${ }^{13}$ It is possible to see such arguments from analogy or definition as directly supporting the practical claim via their entailments. However, I am representing them as subordinated to the arguments from positive or negative consequence because this shows more clearly that: (a) it is in virtue of the known effects of 'gambling', 'execution' or 'surgery' that austerity itself becomes acceptable or unacceptable; (b) it is in virtue of the redefinition present in these supporting premises that the consequences can emerge as nonoverridable in the process of weighing reasons. This also shows why it is possible to use a metaphorical redefinition of austerity as 'bloodbath' in favour of austerity (as in the Sun example): through its entailments, the metaphor will still support the counter-claim (austerity is not the right policy) via the premise which says that the consequences are unacceptable, but the weight of the latter is apparently overridden here by other reasons (the positive consequences). 